\title{
Important Indicators in Increasing Nurse Loyalty in The Covid-19 Pandemic Time
}

\author{
I Wayan Septa Wijaya*, Ida Ayu Oka Martini \\ Universitas Pendidikan Nasional, Denpasar, Indonesia \\ *septawijaya220895@gmail.com
}

\begin{abstract}
Hospital is a means of health efforts that carry out health service activities and is a service provider institution. Health services in a hospital have an important role in achieving success in hospital services. This study aims to determine the effect of intrinsic motivation, leadership, supervision, intrinsic motivation on the satisfaction and loyalty of nurses in Ganesha General Hospital. The number of samples involved was 84 people using random sampling. Data collection was carried out using a questionnaire. Data analysis techniques using smartPLS. The results showed that intrinsic motivation has a positive effect on job satisfaction. Leadership has a positive effect on job satisfaction. Supervision has a positive effect on job satisfaction in nurses. Intrinsic motivation has a positive effect on job loyalty. Supervision has a positive effect on job loyalty. Job satisfaction has a positive effect on job loyalty to nurses at Ganesha General Hospital. The implication of this research is that to obtain high job satisfaction in nurses, strong leadership is needed as well as being able to act as supervisors and have assertiveness in applying discipline.
\end{abstract}

Keywords: Intrinsic Motivation, Job Satisfaction, Leadership, Job Satisfaction, Loyalty 


\section{STRADA Jurnal Ilmiah Kesehatan}

DOI: $10.30994 /$ sjik.v9i2.531

ISSN: 2252-3847 (print); 2614-350X (online)

Vol.9 No.2 November 2020 Page.1763-1770

\section{BACKGROUND}

Hospital is a means of health efforts that carry out health service activities and as a service provider institution. Health services in a hospital have an important role in achieving success in hospital services. Complex services need to be managed professionally by human resources. One of the supporting factors is health workers who must be available 24 hours to treat patients (Nursalam, 2018).

Nursing is a form of professional service that is an integral part of health services based on nursing science and tips in the form of comprehensive or holistic biological, psychological, sociological and spiritual services aimed at individuals, families and communities in a healthy or sick condition that includes all life processes of human beings who refer to nursing professional standards and use nursing ethics as the main demand therefore the contribution given by nursing greatly determines the quality and level of hospital services (Nursalam, 2018).

Nurse is a human resource who plays a role of health services in hospitals because in addition to being a large number, it is also a profession that provides constant and continuous 24-hour service to patients every day. Currently, nurses are professional staff whose roles cannot be excluded from all forms of hospital services. This role is due to the nurse's job requires the longest contact with the patient. Therefore nursing services contribute in determining the quality of service at the hospital therefore every effort to improve the quality of hospital services must also be accompanied by efforts to improve the quality of nursing services (Nursalam, 2018). Based on the background of this problem, this study was intended to determine important indicators in increasing nurse loyalty during the Covid-19 pandemic.

\section{METHODS}

This study used a quantitative method research design to test the models and instruments that have been developed by previous researchers through inferential statistics by using Structural Equation Modeling with the Partial Least Square (PLS) approach. The location of the research was conducted in Ganesha Celuk Sukawati General Hospital, Gianyar. The number of sample used was 84 people. This study was conducted from $2^{\text {nd }}$ to $25^{\text {th }}$ October 2020. This study used a Likert scale questionnaire for data collection. This study used five variables.

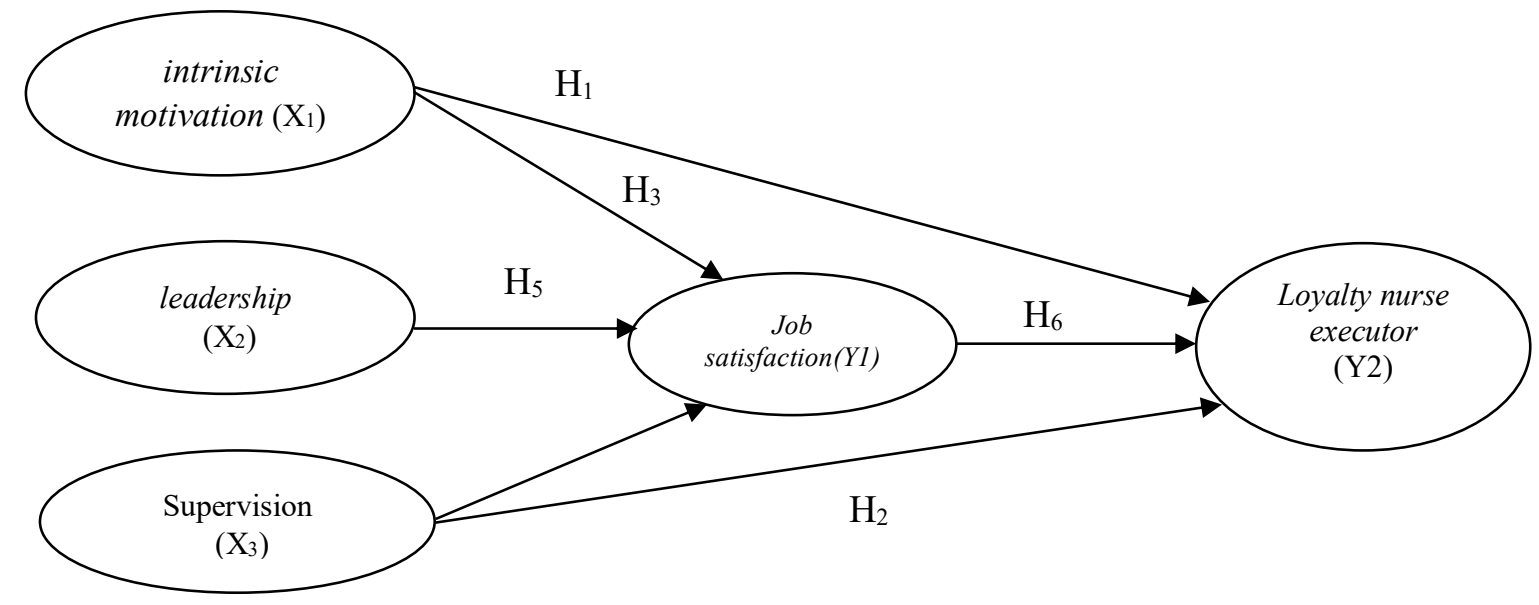

Figure 1. Research Framework 


\section{STRADA Jurnal Ilmiah Kesehatan}

DOI: $10.30994 /$ sjik.v9i2.531

ISSN: 2252-3847 (print); 2614-350X (online)

Vol.9 No.2 November 2020 Page.1763-1770

\section{RESULT}

There were three criteria in using data analysis techniques with SmartPLS to assess the outer model, namely convergent, discriminant, and composite reliability.

Convergent validity of the measurement model with a reflexive indicator was assessed based on the correlation between item or component score estimated by SmartPLS Software. An individual reflexive measure was said to be high if it correlated more than 0.70 with the measured variable. In this study, the loading factor limit of 0.7 was used. The analysis results using PLS could be seen in Table 1. The value of the outer model or the correlation between variables had met the convergent validity because it had a loading factor value above 0.50 .

Discriminant validity, carried out in order to ensure that each concept of each latent variable was different from other variables. The model can be said having good discriminant validity if each indicator loading value of a latent variable had a loading value that was greater than the loading value if it was correlated with other latent variables. The results of discriminant validity testing were in Table 1.

Table 1. Discriminant Validity

\begin{tabular}{lrrrrrrr}
\hline \multicolumn{1}{c}{ Variable } & AVE & $\sqrt{ }$ AVE & Leadership & $\begin{array}{c}\text { Job } \\
\text { satisfaction }\end{array}$ & Loyalty & $\begin{array}{c}\text { Intrinsic } \\
\text { motivation }\end{array}$ & Supervision \\
\hline Leadership & 0,614 & 0,783 & 0,783 & & & & \\
Job satisfaction & 0,793 & 0,891 & 0,585 & 0,891 & & & \\
Loyalty & 0,680 & 0,825 & 0,825 & 0,654 & 0,825 & & \\
Intrinsic motivation & 0,654 & 0,809 & 0,485 & 0,005 & 0,516 & 0,809 & \\
Supervision & 0,670 & 0,819 & 0,43 & 0,392 & 0,503 & 0,409 & 0,819 \\
\hline
\end{tabular}

Based on Table 1, it can be explained that from the results all variables had an AVE value above 0.50 and all variables had an AVE root value higher than the correlation coefficient between one variable and another therefore it could be said that the data had a good discriminant validity.

Composite Reliability, validity and reliability criteria could also be seen from the reliability value of a variable and the Average Variance Extracted (AVE) value of each variable. The variable was said to have high reliability if the composite reliability value was above 0.70 and AVE was above 0.50 . In Table 2, the Composite Reliability value was presented.

Table 2. Composite Reliability

\begin{tabular}{lr}
\hline \multicolumn{1}{c}{ Variable } & Composite Reliability \\
\hline Leadership & 0,863 \\
Job satisfaction & 0,939 \\
Loyalty & 0,914 \\
Intrinsic motivation & 0,904 \\
Supervision & 0,858 \\
\hline
\end{tabular}

Table 2 informed that all variables met composite reliability because their value was above the recommended number, which was above 0.7 which had met the criteria for 


\section{STRADA Jurnal Ilmiah Kesehatan}

DOI: $10.30994 /$ sjik.v9i2.531

ISSN: 2252-3847 (print); 2614-350X (online)

Vol.9 No.2 November 2020 Page.1763-1770

reliability. Based on the overall evaluation results, both were convergent, discriminant, composite reliability, which had been described above, it can be concluded that indicators as measures of latent variables were valid and reliable measures.

The structural model was evaluated by paying attention to the Q2 predictive relevance model which measured how well the observed value was generated by the model.

Table 3. Score $R$-square $\left(\mathrm{R}^{2}\right)$ Endogenous Latent Variables

\begin{tabular}{lc}
\hline \multicolumn{1}{c}{ Variable } & $\boldsymbol{R}$-Square \\
\hline Job satisfaction & 0,504 \\
Loyalty & 0,693 \\
\hline
\end{tabular}

Based on Table 3, the predictive-relevance (Q2) value could be calculated, namely: 1 $(1-0.504)(1-0.693)=0.847$. The results of this calculation indicated that the $Q$ value was greater than $0(0.847>0)$. It could be interpreted that a good model had a relevant predictive value, namely $84.7 \%$ of the variation in the job loyalty variable could be explained by the variables used, while the remaining $15.3 \%$ was explained by other variables that had not been included in the model.

Table 4. Hypothesis Testing Results

\begin{tabular}{llll}
\hline \multicolumn{1}{c}{ Variable } & \multicolumn{1}{c}{$\begin{array}{c}\text { Path Coeffecient } \\
\text { (Bootsrapping) }\end{array}$} & \multicolumn{1}{c}{ T-Statistics } & Conclusion \\
\hline $\begin{array}{l}\text { Intrinsic Motivation for job } \\
\text { satisfaction }\end{array}$ & 0,438 & 3,25 & H1 be accepted \\
$\begin{array}{l}\text { Leadership on job satisfaction } \\
\text { Supervision of job satisfaction }\end{array}$ & 0,677 & 6,279 & H2 be accepted \\
$\begin{array}{l}\text { Intrinsic motivation for } \\
\text { loyalty }\end{array}$ & 0,49 & 3,523 & H3 be accepted \\
\hline
\end{tabular}

Based on the results of tests carried out using the Smart PLS application, an image of the following research model can be presented:

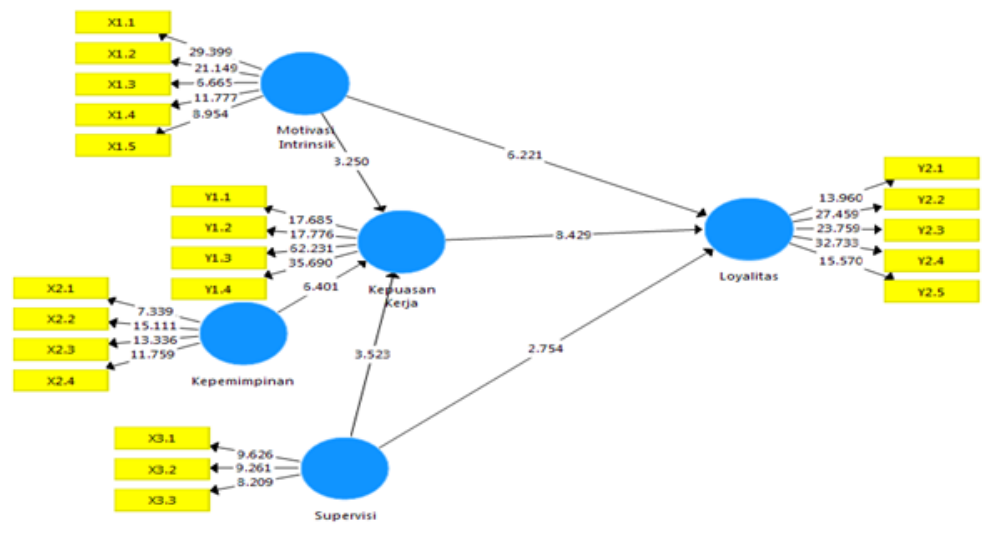

Figure 2. Full Model Structural (PLS Bootstraping) 


\section{STRADA Jurnal Ilmiah Kesehatan}

DOI: $10.30994 /$ sjik.v9i2.531

ISSN: 2252-3847 (print); 2614-350X (online)

Vol.9 No.2 November 2020 Page.1763-1770

Based on the testing results of the research data, it was found that the intrinsic motivation variable on job satisfaction had a standardized estimate (regression weight) of 0.438 , with $\mathrm{Cr}$ (Critical ratio = identical to the t-count value) of 3.250 at a probability of 0.00 . CR value 3,250>2,000 and Probability $=0,000<0.05$ indicated that the influence of the intrinsic motivation variable on job satisfaction was significant.

\section{DISCUSSION}

In this study, intrinsic motivation was measured using indicators of responsibility, achievement, job itself, rewards, and opportunities to develop, illustrating that with high intrinsic motivation it could have an impact on increasing job satisfaction of nurses in Ganesha General Hospital. It was indicated by the positive value of the path coefficient of the intrinsic motivation variable on job satisfaction. The results of the study showed that the higher the intrinsic motivation, the higher the job satisfaction.

Motivation is the energy that moves individuals to strive in order to achieve the expected goals. Basically, motivation is very important to be given to employees because motivation is as encouragement or to provide encouragement to employees therefore they can do their assigned tasks as well as possible. Motivation also has a major effect on employee job satisfaction because employees who are not motivated or encouraged to work will not achieve the predetermined targets, in this case the employees become dissatisfied with the work that has been done.

The results of this study were consistent with what was done by Frianto (2018) which stated that intrinsic motivation had a positive effect on job satisfaction. Similar results were shown in the research of Eka (2016) and Ahmad (2016).

Based on the testing results of the research data, it was known that the leadership variable on job satisfaction had a standardized estimate (regression weight) of 0.677 with a $\mathrm{Cr}$ (critical ratio $=$ identical to the t-count value) of 6.401 at a probability of 0.00 . CR value of $6.401>2,000$ and probability $=0.000<0.05$ indicated that the influence of the leadership variable on job satisfaction was significant.

The leadership variable in this study was measured using indicators of supervisory position, the need for achievement, intelligence, and assertiveness were proven to form leadership variables and proven to be able to influence the job satisfaction variables of nurses in Ganesha Hospital. It was indicated by the value of the path coefficient of the leadership variable on job satisfaction was positive. The results of the study mean that the better the leadership applied by the leadership, the higher the job satisfaction of nurses in Ganesha General Hospital.

The results of this study confirmed the results of previous studies, namely Suprapta (2015) and Rumawas (2015) which proved that leadership had a significant positive effect on job satisfaction. These results reinforced Riyani's (2016) statement that leaders must always be able to feel what employees need therefore employees would feel satisfied. This opinion was confirmed by Simamora (2016) who stated that the role of leaders can affect job satisfaction. According to Nawawi (2018) if the leadership is able to apply proper leadership, then employees will feel satisfied which in the end will be able to improve their performance towards being more productive.

Based on the testing results of the research data, it was known that the supervision variable on job satisfaction had a standardized estimate (regression weight) of 0.279 , with $\mathrm{Cr}$ (Critical ratio $=$ identical to the t-count value) of 3.523 at a probability of 0.00 . CR value 


\section{STRADA Jurnal Ilmiah Kesehatan}

DOI: $10.30994 /$ sjik.v9i2.531

ISSN: 2252-3847 (print); 2614-350X (online)

Vol.9 No.2 November 2020 Page.1763-1770

$3,250>2,000$ and Probability $=0,000<0.05$ indicated that the effect of the supervision variable on job satisfaction was significant.

The supervision variable in this study used normative, formative, and restorative indicators which were proven to form the supervision variable and proven to be able to influence the job satisfaction variables of nurses in Ganesha Hospital. It was indicated by the positive value of the path coefficient of the supervision variable on job satisfaction. The results of the study indicated that the better the supervision was applied by the leadership, the higher the job satisfaction of nurses in Ganesha General Hospital.

Supervision is a provision of important resources to employees in completing tasks in accordance with the stated goals. In carrying out supervision, it needs to be considered and carried out properly because it can affect employee job satisfaction.

The results of this study were consistent with that research conducted by Khamlub (2016) argued that supervision provided by supervisors or superiors was a factor that could lead to job satisfaction. Likewise, the results of research conducted by Syahrir et al (2016) show that there was a correlation between supervision and the implementation of nursing care. The better the supervision could improve the quality of nurses' work. Petrus (2015) stated that there was a correlation between the supervision of the head of the ward and the job satisfaction of the nurse in charge.

Based on the results of testing the research data, it was known that the intrinsic motivation variable towards loyalty had a standardized estimate (regression weight) of 0.490 , with $\mathrm{Cr}$ (Critical ratio = identical to the t-count value) of 6.221 at a probability of 0.00 . The $\mathrm{CR}$ value of $6.221>2,000$ and probability $=0.000<0.05$ indicated that the influence of the intrinsic motivation variable on loyalty was significant.

In this study, intrinsic motivation was measured using indicators of responsibility, achievement, job itself, rewards, and opportunities to develop, illustrating that with high intrinsic motivation it could have an impact on increasing job loyalty of nurses in Ganesha General Hospital. It was indicated by the value of the path coefficient of the intrinsic motivation variable on job loyalty was positive. The results of the study mean that the higher the intrinsic motivation, the higher the job loyalty.

Intrinsic motivation is motivation that comes from within oneself which is a must-have thing. Intrinsic motivation is very important to encourage oneself to achieve a desired goal. According to Robbins, when a person is motivated, he will try his hardest to try. A high level of effort will lead to beneficial and beneficial loyalty results for the organization. Therefore it could be concluded that high motivation could affect the high loyalty of employees.

The results of this study were in accordance with Mahayuni (2020) showed that motivation had an effect on employee loyalty in PT. Mardika Griya Prasta. Similar results were shown by Muhamad (2019), similar results were also shown by Swadarma (2020).

Based on the results of data testing in the field, it was known that the effect of the supervision variable on loyalty had a standardized estimate (regression weight) of 0.156 , with $\mathrm{Cr}$ (Critical ratio = identical to the t-count value) of 2.754 at a probability of 0.00 . The $\mathrm{CR}$ value of $2.754>2,000$ and probability $=0.030<0.05$ indicated that the effect of the supervision variable on loyalty was significant.

The supervision variable in this study used normative, formative, and restorative indicators which were proven to form the supervision variable and proven to be able to influence the job loyalty variables of nurses in Ganesha General Hospital. It was indicated by the value of the path coefficient of the supervision variable on job loyalty was positive. 


\section{STRADA Jurnal Ilmiah Kesehatan}

DOI: $10.30994 /$ sjik.v9i2.531

ISSN: 2252-3847 (print); 2614-350X (online)

Vol.9 No.2 November 2020 Page.1763-1770

The results of the study mean that the better the supervision was applied by the leadership, the higher the job loyalty of nurses in Ganesha General Hospital.

Nursing supervision is a process of providing resources needed by nurses to complete tasks in order to achieve predetermined goals. Supervision enables a nursing supervisor to find various obstacles faced in the implementation of nursing care in the ward concerned through a comprehensive analysis together with nurse members effectively and efficiently. Therefore nurses feel comfortable at work and want to stay in the organization.

The results of the study were consistent with previous research shown by Sugiarto (2016) showing that good nursing supervision had an impact on nurses' desire to continue working in the hospital. The influence of the job satisfaction variable on loyalty had a standardized estimate (regression weight) of 0.629 , with $\mathrm{Cr}$ (Critical ratio $=$ identical to the t-count value) of 8.429 with a probability of 0.00 . CR value of $8,429>2,000$ and probability $=0,000<0,05$ indicated that the effect of job satisfaction variable on loyalty was significant.

Job satisfaction related to intrinsic and extrinsic factors can be fulfilled properly therefore employees would have loyalty to their work. The loyalty of employees could be seen from the employees' interest in their duty done, the atmosphere of the work environment workplace and the working hours (attendance and punctuality of work).

The results of this study were consistent with what had been shown by Anwar (2016) who found that supervision had a significant positive effect on loyalty. Similar results were shown by Ovinda (2016).

\section{CONCLUSION}

This study showed that intrinsic motivation had a positive effect on job satisfaction. Leadership had a positive effect on job satisfaction. Supervision had a positive effect on job satisfaction in nurses. Intrinsic motivation had a positive effect on job loyalty. Supervision had a positive effect on job loyalty. Job satisfaction had a positive effect on job loyalty to nurses in Ganesha General Hospital.

\section{REFERENCES}

Aditya. (2013). Pengaruh Motivasi Intrinsik dan Motivasi Ekstrinsik Terhadap Kepuasan Kerja. Jurnal Bisnis dan Manajemen, 5(1).

Anasrulloh, M. (2019). Kontribusi Gaya Kepemimpinan dan Motivasi Terhadap Loyalitas Karyawan. Jurnal Nusantara Aplikasi Manajemen Bisnis, 4(1), 53-59.

Anogaraga. (2016). Psikologi Kerja. Jakarta: Rineka Cipta.

Anwar. (2016). Pengaruh Kepuasan Kerja Terhadap Loyalitas Staf Reception Pada Hotel X Pada Madiun Jawa Timur. Binus Bisnis Review, 3(1), 493-501.

Ardana. (2016). Manajemen Sumber Daya Manusia. Yogyakarta: Graha Ilmu.

Asmuji. (2018). Manajemen Keperawatan, Konsep dan Aplikasi. Yogyakarta: Erlangga.

Badeni, M. A. (2013). Kepemimpinan dan Perilaku Organisasi. Bandung: Alfabeta.

Bangun. (2018). Manajemen Sumber Daya Manusia. Bandung: Erlangga.

Basri. (2018). Hubungan Supervisi Kepala Ruangan Terhadap Kepuasan Kerja Perawat. Jurnal Maternitas Kebidanan Prima, 3(2).

Bisma. (2018). Pengaruh Motivasi Intrinsik dan Motivasi Ekstrinsik Terhadap Kepuasan Kerja. Journal BISMA (Bisnis dan Manajemen).

Cahyani. (2015). Pengaruh Modal Intelektual Dan Kepuasan Kerja Terhadap Kinerja Pegawai Serta Dampaknya Terhadap Loyalitas Pegavai Customer Service Hotel Berbintang Empat di Kota Bandung. Jurnal Ecodomica, 3(2). 


\section{STRADA Jurnal Ilmiah Kesehatan}

DOI: $10.30994 /$ sjik.v9i2.531

ISSN: 2252-3847 (print); 2614-350X (online)

Vol.9 No.2 November 2020 Page.1763-1770

Dessler. (2017). Manajemen Sumber Daya Manusia. Jakarta: Salemba Empat.

Diansyah. (2018). Pengaruh Kepemimpinan Transforma-sional dan Kompensasi Terhadap Kepuasan Kerja Malalui Komitmen Organsiasi.

Gomes. (2016). Manajemen Sumber Daya Manusia. Andi: Yogyakarta.

Habib. (2019). Analisis Pengaruh Kualitas Pelayanan dan Kepuasan Pelanggan Terhadap Loyalitas Berbelanja Online E-Commerce Shopee. Tesis. Universitas Andalas.

Handoko. (2017). Manajemen Sumber Daya Manusia. BPFE: Yogyakarta.

Hasibuan. (2017). Manajemen Sumber Daya Manusia, Edisi Revisi. PT. Bumi Aksaran: Jakarta.

Hirosawa, Outavong, P., Sakamoto, J. (2016). Job Satisfaction of Khamlub, Senbonsou, Harun Or Rashid. Muhammad Abdul Bashar Sarker, Tomaya Lao PDR. Nagoya Journal Medical Science, 75, 233-241.

Mahayuni. (2020). Pengaruh Kepemimpinan Tranforma-sional, Lingkungan Kerja dan Motivasi Terhadap Loyalitas di PT. Mardika Griya Prasta. E-jurnal Manajemen, 9(5), 1696-1716.

Martini, I. A. O. (2019). The Role of the Employee Work Motivation in Mediating the Work Culture towards Their Performance. Jurnal Ekonomi dan Bisnis Jagaditha, 6(1), 15-21

Martini, I. A. O. (2020). Indikator Penting Dalam Motivasi, Kinerja Karyawan, Disiplin Kerja, Mutu Pelayanan dan Kepuasan Kerja. KINERJA: Jurnal Ekonomi dan Manajemen, 17(1)

Maulana. (2015). Pengaruh Motivasi Intrinsik, Motivasi Ekstrinsik dan Komitmen Organisasi Terhadap Kinerja Karyawan Pada Ban BTN Kantor Cabang Malang. Jurnal Adminiistrasi Bisnis, 6(1).

Murfitriana. (2014). Pengaruh Motivasi Intrinsik, Kedisiplinan, Gaya Kepemimpnan Demokratis, Komitmen Normatif Terhadap Kepuasan Kerja Karyawan PG. Sumberharjo Pemalang. Tesis. Muhamadiyah University, Purwokerto.

Nawawi. (2018). Manajemen Sumber Daya Manusia Untuk Bisni Yang Kompetitif. Yogyakarta: Gajah Mada University Press.

Nursalam. (2018). Manajemen Keperawatan Aplikasi Dalam Praktek Keperawatan Profesional. Jakarta: Salemba Medika.

Riyani. (2016). Manajemen Sumber Daya Manusia Masa Kini. Yogyakarta: Graha Ilmu.

Robbins. (2015). Prilaku Organisasi. Jakarta: Salemba Empat.

Rumawas. (2015). Pengaruh Kepemimpinan Terhadap Kepuasan Kerja Karyawan. Jurnal Adiminstrasi Publik, 4(1).

Simamora. (2016). Manajemen Sumber Daya Manusia, Edisi Kedua. Yogyakarta: STIE YKPN.

Sugiarto. (2016). Pelaksanaan Supervisi Keperawatan Dalam Persepektifk Perawat Perawat Pelaksana di Rumah Sakit Paru dr. Ario Wirawan Salatiga. Fakultas Ilmu Kesehatan, Universitas Muhamadiah Surakarta.

Suprapta. (2015). Pengaruh Kepemimpinan Terhadap Kepuasan Kerja dan Kinerja Karyawan. E-Jurnal Ekonomi dan Bisnis Universitas Udayana, 4(6), 430-442.

Swadarma. (2019). Kompensasi, Motivasi Kerja dan Lingkungan Kerja Terhadap loyalitas karyawan Rame Café Jimbaran Seafood. E-Jurnal Manajemen, 9(5), 1738-1757.

Syahrir, Muluadi, H., Haskas, Y. (2016). Hubungan Supervisi dengan Pelaksanaan Asuhan Keperawatan di Ruang Rawat Inap RSUD Labuang Baji Makasar. Jurnal Keperawatan, 1(1). 